\title{
Pulling in the indigenous fishery cooperative net: Fishing for sustainable livelihoods and food security in Garden Hill First Nation, Manitoba, Canada
}

\author{
Shirley Thompson, ${ }^{a *}$ Mohammad Rony, ${ }^{a}$ and Jennifer Temmer ${ }^{a}$ \\ Natural Resources Institute, University of Manitoba \\ Darcy Wood ${ }^{\mathrm{b}}$ \\ Island Lake Wabung Fisheries Co-op and Aki Energy
}

\begin{abstract}
Submitted January 10, 2014 / Revised March 25, April 28, and May 21, 2014 /
Accepted May 22, 2014 / Published online June 23, 2014

Citation: Thompson, S., Rony, M., Temmer, J., \& Wood, D. (2014). Pulling in the indigenous fishery cooperative net: Fishing for sustainable livelihoods and food security in Garden Hill First Nation, Manitoba, Canada. Journal of Agriculture, Food Systems, and Community Development, 4(3), 177-192.

http://dx.doi.org/10.5304/jafscd.2014.043.016
\end{abstract}

Copyright (C) 2014 by New Leaf Associates, Inc.

\begin{abstract}
Cooperatives offer a vehicle for community development in less-developed countries as well as in economically challenged indigenous communities in developed countries. The authors engaged in a participatory community development research project involving students and faculty working with the Island Lake Opakitawek Cooperative (ILOC), a fishery cooperative in the remote community of Garden Hill First Nation (GHFN) in Manitoba, Canada. The project included four general components: (a) a sustainable livelihoods assessment; (b) a basic community food security assessment; (c) strategic business analysis; and (d) a business plan.
\end{abstract}

${ }^{a}$ Natural Resources Institute, University of Manitoba.

b Island Lake Wabung Fisheries Co-op and Aki Energy; darcywood@akienergy.com

* Corresponding author: Shirley Thompson, Natural Resources Institute, University of Manitoba; +1-204-474-7170; s.thompson@umanitoba.ca
The analysis shows that traditional foodways and livelihoods take advantage of prodigious natural capital, and that this indigenous cooperative offers potential to improve the fishers' quality of life. However, we also found that fishers' livelihoods and the ILOC were not sustainable without significant changes. Together, high operating expenses and low prices for whole fish are impoverishing fishers. Despite the poor return on investment, commercial fishing has continued for decades due to its connection with traditional hunting and fishing activities and the region's high unemployment level. Working collaboratively with the ILOC and GHFN community we have been able to reinvigorate the cooperative based on local food provision and fair trade.

\section{Keywords}

cooperatives, country foods, fishing, local food economy, sustainable livelihoods, indigenous, First Nation, poverty, participatory community development research 


\section{Introduction and Methods}

It is widely understood that cooperatives have been successful in fighting poverty (Bharadwaj 2012; Bibby \& Shaw, 2005; Birchall, 2003; Prasad \& Satsangi, 2013; Wanyama, Develtere, \& Pollet, 2009). Birchall (2004) touts cooperatives' positive impact on poverty reduction, saying, "Their track record over 150 years in lifting whole groups of people out of poverty in the now developed world is substantial" (p. 45). Cooperatives around the world have improved the sustainability of rural livelihoods, in particular in Africa (Wanyama et al., 2008), India (Prasad \& Satsangi, 2013), Nepal (Bharadwaj, 2012), and Bangladesh and Bolivia (Bibby \& Shaw, 2005). Cooperative approaches have successfully addressed socio-economic issues (Wanyama et al, 2008); built capacity, enabled effective supervision, and fostered sustainable livelihoods (Prasad \& Satsangi, 2013); and increased ethical consideration among members, empowered women, and created democratic institutions (Bhradwaj, 2012). The Amul Dairy Cooperative in India, for example, transformed members' social and economic lives by developing participative, yet professional, management. These dairy farmers improved their livelihoods by cutting out the middlemen and creating a variety of new value-added products (Prasad \& Satsangi, 2013). Another dairy farmer cooperative, Milk Vita Cooperative in Bangladesh, enhanced social equity by engaging and empowering women. Additionally, by increasing their earnings tenfold milk producers were able to rise above the poverty line (Bibby \& Shaw, 2005).

Cooperatives have been described as "persons united voluntarily to meet their economic, social, and cultural needs and aspirations through a jointly-owned and democratically-controlled enterprise" (International Cooperative Alliance [ICA], 2012, para. 1). As cooperative members can control their own productive activity, this type of enterprise encourages the principles of equality and freedom, offering potential to alleviate economic poverty and improve livelihoods (Sen, 1999). Thus cooperatives present a culturally appropriate vehicle for sustainable development and food sovereignty in indigenous communities, including rural and remote First Nation fishing communities in Canada.
There is a dearth of research, however, on the impact of cooperatives in North American indigenous communities and their role in food security, sustainable livelihoods, and decolonization of traditional diets. By closely examining the ability of one indigenous fishing cooperative, the Island Lake Opakitawek Cooperative (ILOC) of Garden Hill First Nation (GHFN) in Canada, to improve the community's fortunes, we have begun to fill this gap in the literature.

It should be noted that the trials and tribulations of ILOC provide an important lesson for other cooperatives and communities (including nonindigenous ones). As LaDuke (2002) points out, cooperatives and other businesses would benefit society at large by incorporating an indigenous worldview. An indigenous worldview considers cyclical thinking, reciprocal relations, and responsibilities to the earth and to Creation (Ballard, 2012). An indigenous worldview offers a counterpoint to the more competitive forces that deprive and isolate indigenous people from community, land, culture, medicinal resources, and traditional (also known as "country") foods. It is this indigenous worldview that led to the foundation of the Island Lake Opakitawek Cooperative (ILOC) in 1995, which currently operates a fish processing plant on the outskirts of the GHFN community.

In this participatory community development research project, our team of students and faculty at the University of Manitoba collaborated with ILOC and GHFN to understand the role of cooperatives in an indigenous setting as well as offer practical technical assistance to the ILOC, which has struggled with viability since its inception. Participatory community development research methods were utilized to assess the livelihood and food security status of fishers, analyze the viability of their fishing enterprise, and identify strategies for increasing sustainability. This holistic mixed methods approach included unstructured interviews with cooperative leaders, key tribal officials, and commercial fishing experts; focus groups with fishers; field visits and tours of fishing and processing operations; market research; and a review of business records and practices. This data gathering resulted in four key project outputs: (1) a sustain- 
able livelihoods assessment; (2) a basic community food security assessment; (3) strategic business analysis; and (4) a business plan. This work received institutional approval on March 12, 2013, and the first phase of this ongoing project ended April 30, 2014.

\section{The Setting}

Garden Hill First Nation is located at the northern tip of Island Lake in Manitoba, approximately $610 \mathrm{~km}$ (380 miles) northeast of Winnipeg (see Figure 1). GHFN does not have its own airport, and people must go to a nearby island to access a gravel airstrip. GHFN is accessible via plane, winter road, and/or a boat from Wasagamack and St. Theresa Point First Nations, both of which are approximately $17 \mathrm{~km}$ (11 miles) northeast by boat.

The population in this community is growing rapidly. In 2011, GHFN had a population of 2,776, up 46.3 percent from 1,898 in 2006 with a median age of 18.9 years (Statistics Canada, 2011). The very high birth rates of this youthful population are creating pressure on available housing. Census families number 640, although private dwellings available are limited to 545 (Statistics Canada, 2011). Due to lack of housing, the average number of persons per household is higher at 5.1 than the Manitoba average of 3.8 (Statistics Canada, 2011).

Despite the issues being experienced by the community due to population growth, GHFN has preserved its language, culture, and traditions. Sixty percent of people speak Ojibway-Cree and 14 percent speak Cree as both their mother tongue and the language spoken at home. In addition to valuing their language and social customs, hunting and fishing traditions remain strong (Thompson, Kamal, Alam, \& Wiebe, 2012). Hunting traplines, which were assigned to each family by the colonial government centuries ago to maximize the number of furs being traded to the Hudson Bay Company, are still used for sustenance despite often being located hundreds of kilometers away from the community or even in another province.

\section{Figure 1. Location of Garden Hill First Nation on Island Lake in Manitoba}

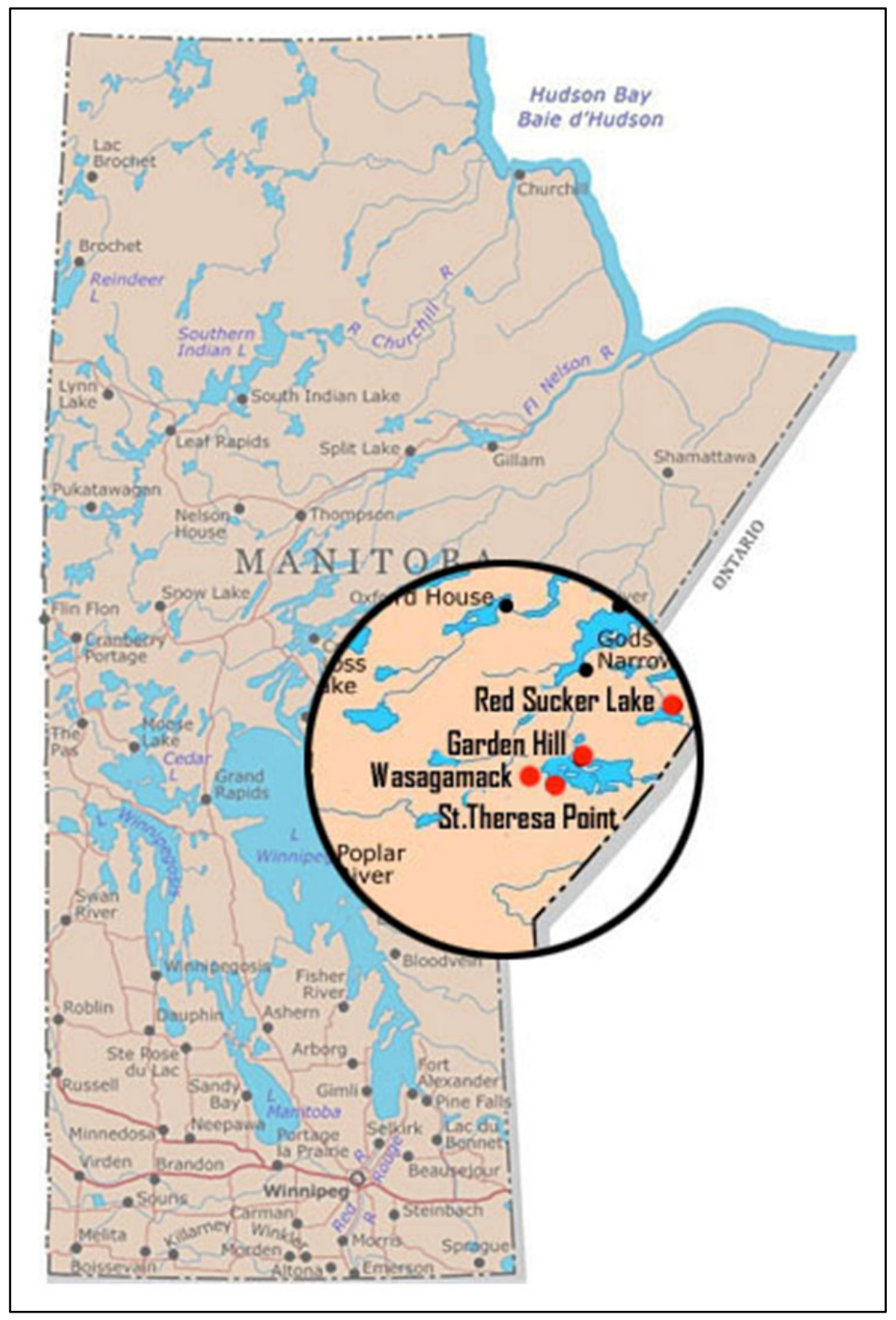

Source: Four Arrows Regional Health Authority. 
Garden Hill Fishers Association and the Island Lake Opakitawek. Cooperative

The Garden Hill Fishers

Association (GHFA) established a cooperative that runs as a social enterprise. Presently having about 50 fisher members, the cooperative was established in 1995 when the government of Manitoba awarded the four Island Lakes First

Nations' fishers with a license to commercial harvest and export fish out of the province but within Canada. Until recently this venture operated under the registered name of Island Lake Opakitawek Cooperative (ILOC) with the export and special dealer's fisher's license granted to GHFA. The cooperative provides high-quality pickerel from the pristine freshwater lakes of northern Manitoba. ILOC has a fish-processing plant located on the outskirts of the GHFN community by the lakeshore (see Figure 2). We became aware of the fishery cooperative during our study of food security rates in 2011 (Islam, Thompson, Zahariuk, \& Mailman, 2011).

In the proceeding sections we present the results of our work in the community in the context of each of the four project outputs.

\section{Project Findings}

\section{Sustainable Livelihoods Assessment}

A sustainable livelihood is defined as "the assets, the activities, and the access to these (mediated by institutions and social relations) that together determine the living gained by an individual or household" (Ellis, 2000, p. 10). Five assets (sometimes referred to as "capitals"), namely natural, physical, human, financial, and social assets, can be used to conduct a sustainable livelihoods assessment. 1 These assets are influenced by processes (e.g., laws, policies, societal norms and incentives)

\footnotetext{
${ }^{1}$ See more about the sustainable livelihoods approach at http://www.fao.org/docrep/006/ad682e/ad682e04.htm\#Top OfPage
}

and institutional structures (e.g., rules, customs and land tenure) that operate at multiple levels (individual, household, community, regional, government, multinational corporations) (Brocklesby \& Fisher, 2003; Carney, 1998; Ellis, 2000; Scoones, 1998, 2009). People approach livelihood strategies based in part on the external environment, including trends, markets, and politics over which they often have little control (Chambers \& Conway, 1992; Department for International Development [DFID], 2001). This complex amalgam of assets and factors have been found useful for assessing the policies causing poverty and underdevelopment on First Nation reserves (Ballard, 2012; Thompson et al, 2012). We analyzed the assets of fishers' families in GHFN to more fully understand the sustainability of their livelihoods.

\section{Human Assets}

Human assets are the skills, health, and education of individuals that contribute to the productivity of labor and capacity to manage land. Human assets are limited in GHFN, given the relatively low levels of education, high rates of chronic unemployment, and high rates of disease compared to other nonFirst Nation communities in Canada (Aboriginal Affairs and Northern Development Canada, 2013).

At present, students in the Island Lake region have to travel to distant urban centers to finish 
their secondary school degree and to seek higher education due to the lack of local or distance learning programs at the college or university level. Compounding the geographical challenge, many of the fishers do not speak or write English, and communicating mainly in Ojibway-Cree poses a major language barrier when negotiating contracts and seeking new business opportunities. In addition to literacy, the community is also challenged by severe health issues. We discovered that GHFN and the other three Island Lake First Nation communities have the highest levels of pediatric diabetes in North America (Amed et al., 2010).

\section{Natural Assets}

Natural or environmental assets are the resources and land management practices in the community. Island Lake and its surrounding lakes and rivers are pristine and have abundant fish. Both local fishers and staff from the Manitoba Conservation office at GHFN consider the mesotrophic lakes in this area to be highly productive and the fishery to be sustainably managed. Mesotrophic lakes have a moderate amount of dissolved nutrients and tend to have the greatest biodiversity.

The harvests in Island Lake and surrounding lakes have always been well below the quota of ILOC's commercial license. Although Manitoba Conservation tracks and quantifies commercial fishing, subsistence fishing is not documented. As most community members do eat local fish for sustenance, the number of fish harvested for subsistence purposes is expected to be high. To prioritize subsistence fishing and ensure that fish are available near where community members live, ILOC fishers do not commercially fish adjacent to the reserve to.

Although the GHFN traditional territory is vast, under Canadian law this First Nation has no regulatory or ownership rights to resources in its territories (Ballard, 2012; LaDuke, 2002; Thompson, Gulrukh, Ballard, Beardy, Islam, Lozeznik, \& Wong, 2011). However, every First Nation community has consultation rights, as well as historical use and occupancy rights, which gives these communities a strong claim to the land and waters in their territory. A land use plan is being created by GHFN with the intention of preserving much of the Island Lake territory and resources, including the fisheries, from industrial development. With the threat of mining in this region that is known for its gold and precious metals, we are currently collaborating to help develop this land use plan to ensure that ancestral land and traditional uses of the land are respected.

\section{Social Assets}

Social assets consist of the close social bonds that facilitate cooperative action as well as the social bridging that facilitates the sharing of ideas and resources between institutions and diverse people. The culture in Island Lake has a norm of reciprocity where community members are expected to do things to help each other and share country foods. The Island Lake community members also highly value traditional activities, such as hunting, fishing, and gathering. The social bonds are clearly evident by how the community television or radio is always on in each home so people can stay informed of community news. If someone needs help, such as a car ride, that person will phone the station and someone in the community will respond to their request if they can.

Once strong, regional and community social bonds have been weakened by reserve settlements, the residential school system that all GHFN residents had to attend, the "Sixties Scoop" (a government practice until the 1980s of sending high numbers of First Nation children to foster homes or putting them up for adoption, usually into white families), and settler education (Ballard, 2012; LaDuke, 2002). These oppressive policies resulted in few opportunities for First Nation people to influence Canadian policies, programs, and their own development (Ballard, 2012; Thompson, Gulrukh, Ballard, et al., 2011; Thompson, Gulrukh, \& Murthy, 2011; Thompson, Lozeznik, \& Klatt, 2011).

\section{Physical Assets}

Physical assets are the equipment and infrastructure in the community that affect the quality of fishers' lives, their business operation, and their productivity. The fish-processing plant, ILOC's biggest physical asset, contains a weighing scale, a blast freezer, and a large space that could be used 
for filleting. However, the fish plant needs many upgrades.

GHFN fishers have limited resources to practice their livelihoods. The small family-sized boats they use lack fish finders, depth meters, or any specialized equipment. Community docks where fish are unloaded are unsafe, with holes large enough for a person to fall through. This poor infrastructure places fishers at high risk for injury or product loss when loading and unloading $25 \mathrm{~kg}$ (55 lb.) boxes of fish.

The fish plant and many GHFN homes do not have access to piped, safe water or sewage facilities. Fifty-one percent of homes have treated water trucked to cisterns or barrels, and 49 percent of homes and the fish plant have no water service at all. Due to the lack of running water, filleting occurs at the school's commercial kitchen so that the product meets Manitoba's public health regulations (see Figure 3).

Without road access, marketing fish is expensive. Winter roads, which are built over lakes, rivers and land, are generally only available from late January to mid-March (East Side Road Authority [ESRA], 2013). A late lake freeze-up and early spring thaw can truncate the window for winter road access as the roads are only useable when there is a thick layer of ice on the lake to support the weight of trucks and cars (ESRA, 2013; Kuryk, 2003). An all-season road of $648 \mathrm{~km}(403$ miles) connecting the Island Lake communities to Norway House Cree Nation is scheduled to be built between 2035 and 2045, with the final road planned for the end of the century (ESRA, 2013). Once an all-season road is in place, shipping costs should decrease.

\section{Financial Assets}

Financial assets are the savings and financial credit of fishers and other community members in GHFN. On the reserve, the land and housing are owned by the federal government (Ballard, 2012). As a result of not owning property,
GHFN people lack the collateral required to obtain credit. Additionally many community members and most fishers lack other regular sources of income. In GHFN, the average median family income is CA $\$ 24,320$ (Statistics Canada, 2011), which is significantly lower than the national average at $\mathrm{CA} \$ 68,400$.

Taken together, the analysis of assets presents a challenging picture. While rich in natural assets, the fishers of GHFN suffer from depleted human, social, physical, and financial capital. This livelihoods assessment hinted at what we would expect to find in our community food security assessment.

\section{Community Food Security Assessment}

Food security occurs "when all people, at all times, have physical and economic access to sufficient, safe and nutritious food that meets their dietary needs and food preferences for an active and healthy life" (Food and Agriculture Organization of the United Nations [FAO], 1996, p. 1). To get a fine-grained view of household food security we conducted surveys with 10 randomly selected fisher households and 41 nonfisher households in GHFN for comparison using a validated instrument from Health Canada (2007). We used the survey to estimate both the prevalence of food insecurity and its severity (Bickel, Nord, Price,

\section{Figure 3. Garden Hill First Nation's Community Members Who Have Food Handling Certificates Fillet Fish at the ILOC Fish Processing and Packaging Facility}

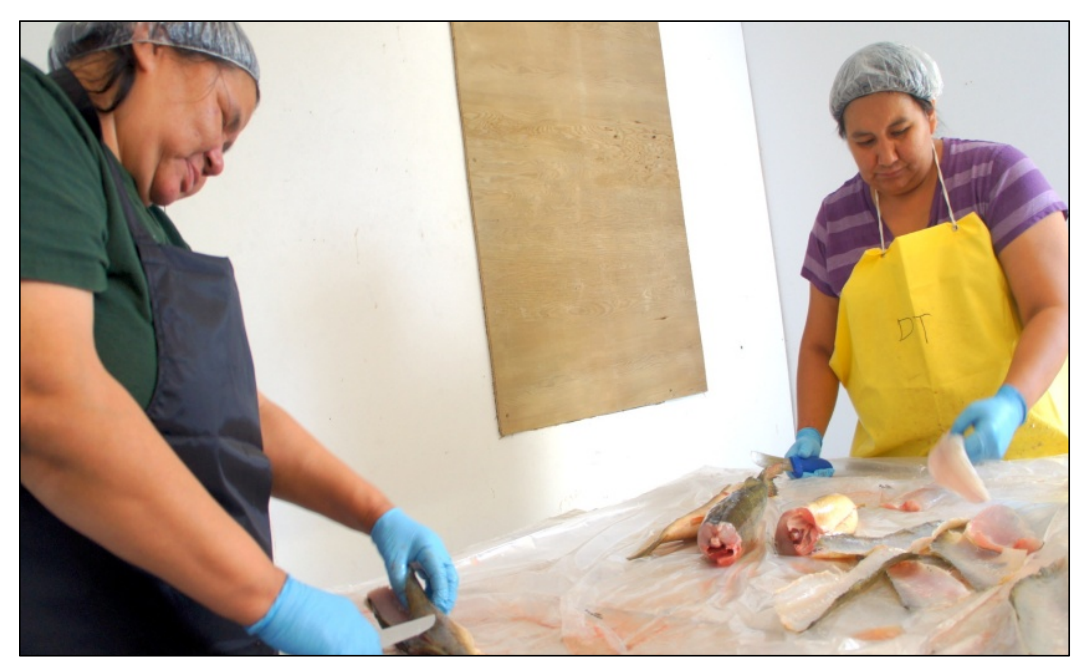

Photo credit: Mohammad Rony 
Hamilton, \& Cook, 2000; Health Canada, 2007) in these two populations.

Food insecurity rates were highest among our samples' fishers families compared to others in the community. Nine fishers' households in GHFN in 2011 were 100 percent severely food insecure (Islam \& Thompson, 2011; Islam, Thompson, Zahariuk et al., 2011). This was higher than the overall high rates in the general population of GHFN, where 42 percent were severely food insecure and another 43 percent were moderately food insecure (Thompson, Gulrukh, Ballard, et al., 2011; Thompson et al., 2012). Severe food insecurity means that the household's food supply was disrupted and that children and/or adults went without food or regularly had to reduce their intake due to having no food and no money to buy more (Power, 1999, 2008; Power \& Tarasuk, 2006). Negative health consequences, which reduce human assets, are expected in fishers' families due to their high food insecurity. Food insecurity is linked to broader food-related health problems such as obesity, heart disease, diabetes, high blood pressure, emotional distress, depression, and low immunity levels (Ford \& Mokdad, 2008; Kirkpatrick \& Tarasuk, 2008; Ledrou \& Gervais, 2005; Scheier, 2005; Willows, Hanley, \& Delormier, 2012).

It should be noted that in addition to availability, accessibility, acceptability, adequacy, and action, sharing food has been identified by Power (2008) as a sixth pillar of food security. The importance of sharing food was supported by a large survey conducted in 14 northern Manitoba communities that found sharing of country foods had a stronger relationship to food security than either road access or competition between stores (Thompson et al., 2012). Country food, the currency of sharing, refers to the mammals, fish, plants, berries, and waterfowl and seabirds harvested from local stocks. Sharing of country food is a traditional way for indigenous communities to deal with food shortages and to foster social networks (Thompson et al., 2012).

Country food access, including fish access, has been restricted by government policies. During our early investigation we learned that serving freshcaught fish at the school or any event without a special dealer's license could result in the federal public health inspectors shutting the school kitchen down temporarily for serving "illegal" fish in a public place (Thompson et al., 2012). Due in part to these restrictions, GHFN fishers and other community members were eating less country foods. This decline in eating country foods shifted the local diet to high-calorie, processed, store-bought food (Thompson, 2005; Thompson, Gulrukh, Ballard et al., 2011), which are widely believed to be associated with increased incidence of obesity, tooth decay, anemia, lowered resistance to infection, diabetes, and food insecurity (Szathmary, Ritenbaugh, \& Goodby, 1987; Thouez, Rannou, \& Foggin, 1989; Willows, Veugelers, Raine, \& Kuhle 2011; Willows et al., 2012).

\section{Strategic Business Analysis}

Building on our assessment of the livelihoods and food security of the fishers, we conducted a strategic business analysis that took employment and foodways into consideration. Our meetings with key informants and focus groups with fishers revealed a number of critical themes which appear to be at the heart of the challenges and opportunities faced by ILOC: (1) traditional sustenance activities have become fused with commercial fishing; (2) commercial fishing is unprofitable; (3) the ILOC engages in poor business practices; and (4) fishers are not aware of their eligibility for employment insurance (EI). These themes were both of academic interest and practical significance for improving livelihoods and business outcomes.

\section{Traditional Sustenance and Commercial Activities Have Become Intertwined}

The commercial fishing season is also hunting and harvesting season; it is the key time for moose, deer, and goose hunting, as well as being an important time to pick traditional herbal medicines. To some degree commercial fishing subsidizes the time spent on sustenance hunting, fishing, and living in the fishers' traditional territory. Many fishers described the hunting, fishing, and gathering as sacred and integral to their culture. As one GHFN band employee explained:

The fishermen love to get out on their trap line and commercial fishing is the excuse to do 
it. They don't even care if they make money as long as they can get out on their trap line to hunt and fish. That's what they live for.

This is a challenge because commercial fishing on the trapline in inland lakes has very high transportation costs. With only ice huts to refrigerate fish and a license that only allowed the selling of whole fish, fish had to be flown out by floatplanes several times a week at great expense to fishers.

\section{Commercial Fishing at GHFN Is Unprofitable}

Our analysis shows that commercial fishers and the ILOC operated in the red. While we estimate fishers out-of-pocket expenses were CA $\$ 6.70 / \mathrm{kg}$ in 2012, they only received CA $\$ 3.52 / \mathrm{kg}$ selling fish commercially, representing a CA $\$ 3.18 / \mathrm{kg}$ loss to fishers. Fish sales by ILOC also operated at a loss. The fish were sold in 2012 for CA $\$ 6.60 / \mathrm{kg}$ (CA $\$ 3.00 / \mathrm{lb})$. However, we estimated that the break-even cost of selling whole fish was CA $\$ 9.88 / \mathrm{kg}(\mathrm{CA} \$ 4.49 / \mathrm{lb})$, representing a loss of CA $\$ 3.29 / \mathrm{kg}$ overall for shipping fish to the Winnipeg market (see Table 1). Contribution margin was calculated to be $C A \$ 2.08$ for the breakeven price per unit minus the variable cost per unit.

Based on our discussions, observations, and the breakeven analysis we found ILOC is not profitable for the following key reasons:

1. High shipping costs. The GHFN community and traditional territory is remote, and government-prescribed trap

Table 1. Breakdown of the Total Cost to Fishers for Commercial Production Based on Year 2012, When Individual Fishers Caught an Average of 2,268 kg (5000 lbs.) (All amounts in CA\$)

\begin{tabular}{|c|c|c|c|c|c|c|}
\hline Item & Unit & $\begin{array}{l}\text { Amount } \\
\text { (CA\$) }\end{array}$ & $\begin{array}{l}\text { Total Quantity } \\
\text { (kg) }\end{array}$ & $\begin{array}{l}\text { Total Quantity } \\
\text { (Ib) }\end{array}$ & $\begin{array}{c}\text { Cost } \\
\text { (per Kg) }\end{array}$ & $\begin{array}{c}\text { Cost } \\
(\text { per Ib) }\end{array}$ \\
\hline \multicolumn{7}{|c|}{ Variable Costs (paid by individual fishers) } \\
\hline Fuel & $\$ 1.69 / \mathrm{L}$ & $\$ 4,331.88$ & 2,268 & 5,000 & $\$ 1.91$ & $\$ 0.87$ \\
\hline Engine oil & $\$ 8 / q t$ & $\$ 907.20$ & 2,268 & 5,000 & $\$ 0.40$ & $\$ 0.18$ \\
\hline Air transport & $\$ 450 /$ trip of 4 & $\$ 5579.28$ & 2,268 & 5,000 & $\$ 2.46$ & $\$ 1.12$ \\
\hline Boat/motor repairs & --- & $\$ 204.12$ & 2,268 & 5,000 & $\$ 0.09$ & $\$ 0.04$ \\
\hline $\begin{array}{l}\text { Fishing supplies } \\
\text { (nets, lines, etc.) }\end{array}$ & -- & $\$ 997.92$ & 2,268 & 5,000 & $\$ 0.44$ & $\$ 0.20$ \\
\hline Total Variable costs & --- & $\$ 12,020.40$ & 2,268 & 5,000 & $\$ 5.30$ & $\$ 2.41$ \\
\hline $\begin{array}{l}\text { Contribution margin at break- } \\
\text { even price }\end{array}$ & & & 2,268 & 5,000 & $\$ 4.58$ & $\$ 2.08$ \\
\hline \multicolumn{7}{|c|}{ Fixed Costs (Paid by Individual Fisher) } \\
\hline $\begin{array}{l}\text { Capital purchases (boat, } \\
\text { motor etc.) }\end{array}$ & & $\$ 3,000.00$ & 2,268 & 5,000 & $\$ 1.32$ & $\$ 0.60$ \\
\hline Depreciation & $\begin{array}{c}5 \% \text { annual } \\
\text { depreciation }\end{array}$ & $\$ 150.00$ & 2,268 & 5,000 & $\$ 0.07$ & $\$ 0.03$ \\
\hline Fishing license & Annual renewal & $\$ 12.00$ & 2,268 & 5,000 & $\$ 0.00$ & $\$ 0.00$ \\
\hline Total Fisher Fixed Cost & & $\$ 3162.00$ & 2,268 & 5,000 & $\$ 1.39$ & $\$ 0.63$ \\
\hline \multicolumn{7}{|l|}{ Fixed Costs (Paid by ILOC) } \\
\hline Running fish plant \& freezer & & $\$ 5,000.00$ & 2,268 & 5,000 & $\$ 2.20$ & $\$ 1.00$ \\
\hline $\begin{array}{l}\text { Shipment of fish by air to } \\
\text { Winnipeg }\end{array}$ & & $\$ 2,100.00$ & 2,268 & 5,000 & $\$ 0.92$ & $\$ 0.42$ \\
\hline Miscellaneous (estimate) & & $\$ 150.00$ & 2,268 & 5,000 & $\$ 0.07$ & $\$ 0.03$ \\
\hline Total ILOC Fixed Cost & & $\$ 7,250.00$ & & & $\$ 3.19$ & $\$ 1.45$ \\
\hline Total Fixed Cost (ILOC \& Fisher) & & $\$ 10,412.00$ & & & & \\
\hline Break-even Price & & & & & $\$ 9.88$ & $\$ 4.49$ \\
\hline
\end{tabular}


lines on Island Lake are often hundreds of kilometers away from the packing plant. With no roads to provide easy access or electricity to allow refrigeration of fish, floatplane transport to the GHFN packing plant costs an estimated CA $\$ 2.46 / \mathrm{kg}$, an expense borne by ILOC and the fishers rather than the fish buyers.

2. Low prices received. With transportation expenses unavoidable, fishers operate at a loss selling at the prices offered by buyers. The 2012 price paid for whole headless pickerel was CA $\$ 4.15 / \mathrm{kg}(\mathrm{CA} \$ 1.89 / \mathrm{lb})$, which is not sufficient to cover the estimated total expense of CA $\$ 9.88 / \mathrm{kg}$ $(\mathrm{CA} \$ 4.49 / \mathrm{lb})$ to catch, process, and transport the pickerel.

\section{Lack of planning and resources to make} improvements. The fishery lacked a business plan to adequately address these problems, and lacked the resources to finance start-ups or to upgrade its facilities. One First Nation band councilor complained that the First Nation band always had to subsidize the fisheries: "Each year the band contributes money to fix up the plant and the freezer and get the fisheries started. It is a lot of money every year."

\section{Hegemony of the Freshwater Fish}

Marketing Corporation (FFMC)

The Freshwater Fish Marketing Corporation (FFMC), created by the national government to prevent competition that would drive down freshwater fish prices, regulates all freshwater fish sales in central Canada. With the exception of a few special dealer licenses that FFMC gave to interprovincial vendors, the FFMC became the only seller of freshwater fish in central Canada (FFMC, 2010).

The monopoly by FFMC hampers fish trade in northern Manitoba. Public health officers strictly enforce regulations that all fish must be inspected by FFMC before sale to public institutions (FFMC, 2010). This restriction curtails selling locally to community institutions. As a result, the school kitchen, sport fishing lodges, and other public venues in GHFN were temporarily shut down when public health officials caught them serving local, healthy fish not inspected in a federal facility. These shutdowns were very disruptive; for example, they prevented children and youth from receiving lunch programs for days or weeks.

Fishers in northern Manitoba were more negatively affected than southern fishers by the FFMC monopoly. In addition to marketing, FFMC maintains a monopoly on processing fish; all fish have to be processed by the FFMC processing plant before export outside the province. This restriction put an end to the filleting operations run by the ILOC. Overnight, all the women employed filleting fish lost their jobs, and fishers faced higher transport costs as they were obliged to transport whole fish. The disadvantages to northern fishers were the greater distances and logistical difficulties involved with transporting by plane whole headless fish on ice. Due to the increased transportation costs, fishers had to pay to meet FFMC requirements, and commercial fishing became a losing proposition for fishers living in remote communities.

\section{Poor Business Practices Identified at ILOC}

Poor business practices at ILOC were identified in our focus groups, with numerous complaints about financial, business, and information mismanagement. The accuracy and timing of information were clearly problematic, and there are delays in getting the annual start-up funds, paying transportation bills from previous years, and securing a buyer contract.

The fishers also expressed concerns about financial management, including missing funds and inappropriate expenses being charged: "CA $\$ 15,000$ was unaccounted for last year and when the fishers got CA $\$ 300$ start-up to get their gear for fishing and get to the trap line for their fishing season, so did each of the councilors." An accounting system that requires multiple directors to sign checks was identified as necessary.

The ILOC's finances are further complicated by its dependence on the chief and council to obtain start-up funding, as ILOC has no bank account or line of credit. The fishery was depend- 
ent on the Mikisew Store, a small gas and grocery merchant, for all financial services after the band became third-party managed. (After the band fell into debt the federal government required all band finances to be administered by a for-profit accounting firm, which took a sizeable portion of the small budget for housing, governance, and community development.) In 2012 the store provided the fishers credit notes at CA $\$ 3.62 / \mathrm{kg}$ (CA $\$ 1.60 / \mathrm{lb}$ ) immediately when the pickerel came to the packing plant, as most fishers required daily funding for gas in order to continue fishing. The store recouped its investment throughout the season from fish sales revenue and from fishers purchasing their food and gas from the store; fishers were required to do so as a condition for receiving credit notes.

Fishers expressed concerns about the ecologically sustainability of the fishery, including the need to diversify the species marketed and not waste by-catch. Sales are currently limited to pickerel, which represents 25 percent of the total catch (Thompson et al., 2012). One fisher estimated 75 percent of fish are thrown from the nets due to lack of markets and prices being too low to cover freight costs for by-catch (e.g., white fish, lake trout, walleye, suckers, perch, etc.). He maintained, "We need a way to sell all our fish, not just a small fraction of them." These by-catch fish are now left on the shore of the lake to feed wildlife. If the fishers could sell by-catch locally or smoke these fish to increase their price, pressure on pickerel supplies would be reduced.

\section{Missed Opportunity}

ILOC fishers are losing money by not being aware of changing federal policies and rules. A decade ago the Canadian government changed the unemployment insurance (EI) eligibility rules to accommodate the massive unemployment of fishers after the East Coast cod collapse and subsequent moratorium on cod sidelined most fishers. Until this project, GHFN fishers were unaware of the government changes and their new eligibility. Due to the extremely high unemployment rate in this region, the minimum annual commercial fish sales for EI eligibility is CA $\$ 2,500$ (Service Canada, 2011a). As most fishers sell between $C A \$ 2,500$ and $C A \$ 10,000$ per year, most are eligible for EI. However, due to lack of knowledge, the fishers collect social assistance (welfare) despite EI providing higher rates; unlike social assistance, they are not limited to one EI collector per household. On social assistance, fisher families remain food insecure, as the amount of social assistance is not indexed to account for the much higher food and gas prices on remote First Nation reserves.

According to industry experts, $\mathrm{EI}$ is a necessary subsidy for fishers; northern non-First Nation communities are using EI because they have more social capital, including better information networks. An industry representative stated, "Fishers cannot make money from selling fish... Fishers in northern Manitoba only make a livable wage from EI" (focus group discussion, 2013). Another industry expert affirmed that EI was more profitable than fishing, saying, "You can make three to five times the money on EI for fishing than from selling fish" (focus group discussion, 2013). EI could deliver an estimated half a million to a million dollars per year to the GHFN community, if 30 to 50 fishers there applied. This would substantially improve the livelihoods of fishers' households and the whole community.

\section{Business Plan}

During the course of our project, due to cash flow problems the ILOC fell behind in its payments to Perimeter Airlines, which transported the fish from Island Lake to markets in Winnipeg. The airline operator required a business plan from the ILOC before resuming shipping, but there was no business expertise to draw on within ILOC. ILOC requested that we develop a business plan as part of our university research program. We used a collaborative process with the fishers that considered the existing operation, markets, financial arrangements, and visions for the future. As many of the fishers were not highly literate, we did everything orally, including reviewing the plan and analyzing it line by line out loud, to ensure that (a) the fishers could provide feedback, (b) they shaped the vision, mission, objectives, and (c) they agreed with the financial analysis, which had never previously been undertaken. The key components of the 
business plan included:

- Mission, vision, and objectives

- Market analysis

- Competitive SWOT analysis

- Strategic partnerships and alliances

- Operations and supply chain management

- Marketing and branding strategy

- Break-even analysis

- Sales forecast, cash flow, and income statements

- Risks and mitigation

- Evaluation and impact assessment

- Timeline of key milestones

- Implementation plan

The mission approved by the fishers for the cooperative business plan was 'To support fishers' traditional livelihoods and enhance the community's economic and social condition" (GHFA, 2013, p. 6). The vision was "A healthy and prosperous fishery and community for today and tomorrow" (GHFA, 2013, p. 6). The GHFA fishers adopted the following objectives: "to develop local, provincial and inter-provincial markets for fish products; to ensure a better price for fisherman by implementing a direct marketing system; to create positive economic impact within the community; to earn customer loyalty by establishing brand image for northern products; and to develop entrepreneurship/livelihood capacities among Garden Hill Community members." A copy of the business plan may be obtained by contacting the lead author.

\section{Project Outcomes}

Over the course of our three-year participatory community development research project, our engagement with the ILOC led to four specific outcomes: (1) expanding the local market; (2) adding value and positioning exports as fair trade products; (3) improving management systems for ILOC; and (4) creating a social net through employment insurance. The progress to date on each of these is described below.

\section{Expanding the Local Market by Selling}

Through the Country Foods Program

We observed that the ILOC is growing social capital by building bonds in the community by sharing resources. The First Nation is setting up a Country Foods Program (CFP) in its health center to improve the health and food security of its community. The GHFN Health Center will be upgrading its kitchen and has committed to spending at least 10 percent of its $C A \$ 10,000 /$ year budget on the purchase of local whitefish and other species. This is enough to feed 20 to 50 people in the community each weekday. A number of diabetic elders reported that eating whitefish lowered their blood sugar levels. We also have noted that health workers are shifting their purchases from processed store-bought food to local fish. Educational programming related to the CFP is being developed to engage fishers to teach schoolchildren and youth how to live off the land by hunting and fishing.

\section{Adding $V$ alue and $A d d i n g V$ alues}

In addition to making more fish available locally, the project team identified the need to process and sell value-added fish products (fish fillets and smoked fish) locally and elsewhere in Manitoba. However, since sales and processing had to be approved by FFMC, the fishers felt they could not proceed to process fish without a special dealer license. On the ILOC's behalf, we requested this license from FFMC in 2012. Using videos and statistics, we helped demonstrate to officials that fishers in GHFN needed this license to assist them in developing their livelihoods, reducing poverty, and improving food security.

A special dealer license was granted to ILOC by FFMC for one year in April 2012. This license was renewed the next year for three years, until April 2016. This license allows the Garden Hill Fishers Association and/or fishers to sell legally to the school, health center, and GHFN band office for public events, and to process fish in a commercial kitchen for sale within the province. Different kitchens are being used for this purpose based on availability, including the secondary school kitchen and the health center kitchen. Also, a small-scale pilot filleting operation was started in 
2013 as a means of value-adding and opening new market opportunities. Filleted fish sold for slightly above the fishers' costs when prices were $\mathrm{CA} \$ 5.50 / \mathrm{kg}(\mathrm{CA} \$ 2.50 / \mathrm{lb})$ for whole fish (paid to fishers) and CA $\$ 5.50 / \mathrm{kg}$ for filleting the fish (paid to filleters). For filleting, we were able to play a supportive role by supervising the first two filleting programs, bankrolling the operation, providing packaging, and delivering the fish from the Winnipeg airport to the store. After two shipments that were supervised by University of Manitoba students with food handling licenses, the community organized its own filleting and shipping of fish to Neechi Cooperative. Neechi Cooperative bought several hundred pounds of filleted fish in 2013 at $\mathrm{CA} \$ 13.20 / \mathrm{kg}(\mathrm{CA} \$ 6.00 / \mathrm{lb})$ for pickerel and $\mathrm{CA} \$ 9.90 / \mathrm{kg}(\mathrm{CA} \$ 4.50 / \mathrm{lb})$ for by-catch.

With a new marketing strategy for the valuesadded products, including banners, a video-based commercial, and a social marketing platform, we were able to help the ILOC reposition itself as a fair trade producer. The growing interest in fair trade fish and local food provides increasing potential for marketing local fish from ILOC at premium prices. Discussions have started about extending this business arrangement to other products such as blueberries, herbal teas, and arts and crafts. After hearing about our work helping ILOC implement its business plan, a GHFN artist approached us to help start another cooperative. Now a number of artists from GHFN, including one stone carver with pieces in Winnipeg Art Gallery, are in the process of starting an artists' cooperative in GHFN.

\section{Improving Management for ILOC}

In a gesture reflecting their hope for the future, the fishers elected to revise their name from ILOC Limited to Island Lake Wabung Fisheries Co-op. Wabung has a literal Ojibway-Cree translation of "tomorrow." This new name has been officially registered but all the directors have not signed off on the articles of incorporation under the Cooperatives Act. Due to this delay, although the name will soon be changed, we used the old name, ILOC, throughout this paper.

ILOC also held several business meetings in early 2014 and elected a new slate of directors.
Two well-respected elder fishers were elected as president and vice president. The other three positions were filled by capable people with the skills needed to carry out their jobs, namely an accountant as the treasurer; a business leader with expertise in governance, as well as marketing, as the secretary; and a community health worker with the job of setting up the Country Foods Program as the member-at-large. Financially ILOC is gaining autonomy by opening its own bank account. ILOC has also committed to improve its bottom line and has already implemented various aspects of the 2013 business plan.

\section{Creating a Social Net Through Employment Insurance} EI could subsidize fishers' low wages and provide enhanced benefits over social assistance, and many are considering applying. Although selling CA $\$ 2,500$ to $C A \$ 10,000$ per year of fish provides insufficient income to feed a fisher's family and meet other basic needs, with EI supplementing their fishing income these families will not go hungry, or at least will not go hungry not as often.

\section{Conclusion}

Many people in First Nation communities feel they have been "studied to death." Researchers have come, gathered data, and never been heard from again. In contrast, our participatory community development research project generated useful data and built community capacity to address food security and improve livelihoods. As researchers, we worked alongside the fishers to try to improve their livelihoods in culturally appropriate ways.

The sustainable livelihoods assessment identified policies that have restricted many assets in First Nation communities. Fishers in GHFN had limited assets due in part to government policies underfunding First Nation communities and restricting access to country foods. Logistical difficulties result from the paucity of physical assets, with a lack of safe boat docks, trap lines, banks, roads to access markets, etc. To improve sustainable livelihoods, government investment is needed to improve infrastructure in First Nation and northern communities (e.g., roads, safe water systems, housing, and public transit). In addition, ILOC and all four of the Island Lake First Nation 
communities have limited financial assets, without any banking services in their area. Considering its responsibility for these circumstances, the federal government faces a moral obligation to offer financial services in these poverty-stricken communities.

Human assets are diminished by food insecurity. Shifting spending of community organizations to local fish, and thereby keeping food and money cycling in the community, is expected to decrease local food insecurity. The Country Foods Program, which will offer some funding to fishers, provides a community-based and traditional approach to deal with food insecurity by sharing rather than depending on the market system.

Other assets are plentiful. Natural and social assets related to the commercial fisheries are abundant. GHFN fishers fish on pristine lakes with good supplies of fish. Commercial fishing is valued as it is firmly intertwined with the Ojibway-Cree traditional lifestyle of living off the land and of subsistence food provisioning. Although in the past social capital perpetuated the fisheries even though fishers lose money on the endeavor, these assets could be better used to their marketing advantage to provide a fair trade First Nation brand. Higher prices (from niche marketing) for ILOC fish are expected. The richness of resources and the high cultural value placed on fishing can be leveraged, if matched with the financial means and physical assets, in a way that increases human assets.

Our work on the business plan advanced the fishery's business interests immediately. The plan also laid out a long-term vision and strategy to build sustainable livelihoods, food security, and capacity. Collaboratively, we identified a few options to improve fishers' livelihoods. First, fishers will work with the school and health center to include local fish in lunches, snacks, and the new Country Foods Program. This local food economy has the potential to provide additional income for fishers, a healthier lunch and snack community program, and to contribute to overall improved food security. Second, we have shown that fishers can produce and market value-added fair trade products such as filleted and eventually smoked fish. By returning to traditional ways of smoking fish (modernized to meet public health codes), the fishers could simultaneously increase the value of fish, reduce spoilage risk, and decrease transportation costs.

Third, we found that in order to provide more sustainable livelihoods and food security, the new Island Lake Wabung Fisheries Co-op (ILWFC) requires better management and leadership. Members of the cooperative have begun to make significant organizational changes in these directions, including creating a board of directors and new staff positions to ensure the orderly management of the co-op. Finally, we have helped fishers realize they would benefit more from Employment Insurance than from welfare, as the returns are higher and not limited to one EI collector per household. The increase in fishers' incomes would bring millions of dollars into GHFN. With EI supplementing fishing incomes, fisher families would not go hungry as often.

We believe that with the approaches described above for the new Island Lake Wabung Fisheries Co-op puts it on a path toward decolonization. The GHFN fishers, by prioritizing local food security, traditional culture, and environmental stewardship in their business plan, demonstrate an approach to sustainable development that can inform the efforts of other indigenous and nonindigenous cooperatives. It is our conclusion that in balancing the indigenous worldview approach to cooperatives with a competitive business strategy based on fair trade, the ILWFC will find its place in the regional marketplace and enhance the sustainability of its fishers' livelihoods.

\section{Acknowledgements}

This research received financially support through the SSHRC Insight Grant Award called "The good life through indigenous community development: Sustainable development planning to build community assets in Island Lake First Nation." The authors give special thanks to Larry Wood, Zack \& Val Flett, Steve McDougall, Ivan Harper, and other GHFN community members for their support. The authors thank Bethann G. Merkle (http://www.commnatural.com) for editorial support. 


\section{References}

Aboriginal Affairs and Northern Development Canada. (2013). Aboriginal demographics and well-being. Retrieved from http://www.aadnc-aandc.gc.ca/ DAM/DAM-INTER-HQ-AI/STAGING/textetext/rs re pubs demograph wellbeing PDF 1358 863272403_eng.pdf

Amed, S., Dean, H. J., Panagiotopoulos, C., Sellers, E. A. C., Hadjiyannakis, S., Laubscher, T. A.,...Hamilton, J. K. (2010). Type 2 diabetes, medication-induced diabetes, and monogenic diabetes in Canadian children: A prospective national surveillance study. Diabetes Care, 33(4), 786-791. http://dx.doi.org/10.2337/dc09-1013

Ballard, M. (2012). Flooding sustainable livelihoods of the Lake St Martin First Nation: The need to enhance the role of gender and language in Anishinaabe knowledge systems (Doctoral thesis). Natural Resources Institute, University of Manitoba, Winnipeg, Manitoba.

Bharadwaj, B. (2012). Roles of cooperatives in poverty reduction: A case of Nepal. Administration and Management Review, 24(1), 120-139. http://www.nepjol.info/index.php/AMR/article/ view $/ 7237$

Bibby, A., \& Shaw, L. (Eds.). (2005). Making a difference: Co-operative solutions to global poverty. London: Cooperative College.

Bickel, G., Nord, M., Price, C., Hamilton, W., \& Cook, J. (2000). Guide to measuring household food security (2000 Revision). Alexandria, Virginia: United States Department of Agriculture; Office of Analysis, Nutrition, and Evaluation. Retrieved from www.fns.usda.gov/fsec/files/fsguide.pdf

Birchall, J. (2003). Rediscovering the cooperative advantage: Poverty reduction through self-help. Geneva: Cooperative Branch, International Labour Office. Retrieved from the ACDI/VOCA website: http://www.acdivocacoopex.org

Birchall, J. (2004). Cooperatives and the Millennium Development Goals. Geneva: International Labour Office. Retrieved from http://staging2.ilo.org/public/english/support/lib $\angle$ resource/subject/coop/birchallbook_2004.pdf

Brocklesby, M. A., \& Fisher, E. (2003). Community development in sustainable livelihoods approaches - an introduction. Community Development Journal, 38(3), 185-198.

http://dx.doi.org/10.1093/cdj/38.3.185
Carney, D. (1998). Sustainable rural livelihoods: What contribution can we make? London: Department for International Development, University of Sussex.

Chambers, R., \& Conway, G. R. (1992). Sustainable rural livelihoods: Practical concepts for the 21st century (IDS Discussion Paper No. 296). Brighton, UK: Institute of Development Studies. Retrieved from https://www.ids.ac.uk/publication/sustainablerural-livelihoods-practical-concepts-for-the-21stcentury

Department for International Development [DFID]. (2001). Sustainable livelihoods guidance sheets. London: Author. Retrieved from http://www.efls.ca/web resources/DFID_Sustainable_livelihoods_guidance _sheet.pdf

Ellis, F. (2000). Rural livelihoods and diversity in developing countries. Oxford, UK: Oxford University Press.

East Side Road Authority [ESRA]. (2013). The Manitoba East Road Authority home page. Retrieved July 14, 2013, from http://www.eastsideroadauthority.mb.ca/

Four Arrows Regional Health Authority [FARHA]. (2013). Island Lake. Retrieved July 14, 2013, from http://www.fourarrowsrha.ca/island-lake/

Food and Agriculture Organization of the United Nations [FAO]. (1996). World Food Summit: Rome declaration on world food security and World Food Summit plan of action. Retrieved from http://www.fao.org/ docrep/003/w3613e/w3613e00.htm

Ford, E. S., \& Mokdad, A. H. (2008). Epidemiology of obesity in the Western Hemisphere. Journal of Clinical Endocrinology and Metabolism, 93(11, Supp. 1), 1-8. http://dx.doi.org/10.1210/jc.2008-1356

Freshwater Fish Marketing Corporation [FFMC]. (2010). Corporate framework. Retrieved October 22, 2011, from http://www.freshwaterfish.com/ content/pages/supply-chain-0

Garden Hill Fishers Association [GHFA]. (2013). The Garden Hill Fishers Association Business Plan. Garden Hill First Nation and the University of Manitoba. Copy on file with lead author.

Health Canada. (2007). Canadian Community Health Survey Cycle 2.2, Nutrition (2004): Income-related household food security in Canada (HC Pub. No. 4696). Ottawa: Author. Retrieved from http://www.hc-sc.gc.ca/ fn-an/alt formats/hpfb-dgpsa/pdf/surveill/ income food sec-sec alim-eng.pdf 
International Cooperative Alliance [ICA]. (2012). Cooperative identity, values \& priniciples. Retrieved August 30, 2013, from http://ica.coop/en/whats-coop/co-operative-identity-values-principles

Islam, D., \& Thompson, S. (2011). Community economic development with Neechi Foods: Impact on Aboriginal fishers in northern Manitoba, Canada. Journal of Aboriginal Economic Development, 7(2), 2-7. http://www.edo.ca/edo-tools/jaed

Islam, D., Thompson, S., Zahariuk, S., \& Mailman, M. (2011). Garden Hill First Nation Household Food Survey Shows Food Prices are Unaffordable for Community and its Fishermen: Winnipeg based fish market will help fishermen survive. Poster session presented at the 2011 Annual Conference of the Environmental Studies Association of Canada [ESAC], Winnipeg. Retrieved from http://slideplayer.us/slide/1706076/

Kirkpatrick, S. I., \& Tarasuk, V. (2008). Food insecurity in Canada: Considerations for monitoring. Canadian Journal of Public Health, 99(4), 324-327. http://www.cpha.ca/en/cjph.aspx

Kuryk, D. (2003, June). Winter roads in Manitoba. Paper presented at the $12^{\text {th }}$ Workshop of Hydraulics of Ice-covered Rivers, Edmonton, Alberta. Retrieved from http://cripe.civil.ualberta.ca/Downloads/ 12th Workshop/Kuryk-2003.pdf

LaDuke, W. (2002). The Winona LaDuke reader: A collection of essential writings. Penticton Indian Reserve, B.C.: Theytus Books.

Ledrou, I., \& Gervais, J. (2005). Food insecurity. Health Reports, 16(3), 47-50. http://www.statcan.gc.ca/ pub/82-003-x/4060784-eng.htm

Power, E. M. (1999). Combining social justice and sustainability for food security. In M. Koc, R. MacRae, L. J. A. Mougeot, \& J. Welsh (Eds.), For bunger-proof cities: Sustainable urban food systems (pp. 30-37). Ottawa: IDRC Books.

Power, E. M. (2008). Conceptualizing food security for Aboriginal people in Canada [Commentary]. Canadian Journal of Public Health, 99(2), 95-97. http://www.cpha.ca/en/cjph.aspx

Power, E. M., \& Tarasuk, V. (2006, March). The impact of income on healthy eating in Canada. Health Canada Policy Forum, 60.

Prasad, R., \& Satsangi, R. (2013). A case study of Amul Co-operative in India in relation to organizational design and operational efficiency. International Journal of Scientific and Engineering Research, 4(1), 1-9. http://www.ijser.org/

Scheier, L. M. (2005). What is the hunger-obesity paradox? Journal of the American Dietetic Association, 105(6), 883-885.

http://dx.doi.org/10.1016/j.jada.2005.04.013

Scoones, I. (1998). Sustainable rural livelihoods: A framework for analysis (IDS Working Paper No. 72). Brighton, UK: Institute of Development Studies, University of Sussex. Retrieved from https://www.ids.ac.uk/ publication/sustainable-rural-livelihoods-aframework-for-analysis

Scoones, I. (2009). Livelihoods perspectives and rural development. Journal of Peasant Studies, 36(1), 171-196. http://dx.doi.org/10.1080/03066150902820503

Sen, A. (1999). Development as freedom. Toronto: Random House of Canada.

Service Canada. (2011). Employment insurance benefits for fishers. Retrieved from http://www.servicecanada. gc.ca/eng/ei/publications/fishing.pdf

Statistics Canada. (2011). National Household Survey Profile, Garden Hill First Nation, IRI, Manitoba, 2011.

Retrieved September 30, 2013, from http://www12.statcan.gc.ca/nhs-enm/2011/dp$\mathrm{pd} /$ aprof $/$ details/page.cfm?Lang $=\mathrm{E} \& \mathrm{Geo} 1=\mathrm{CSD}$ $\underline{\& \text { Code } 1=4622048 \& D a t a=\text { Count } \& \text { SearchText }=\text { gar }}$ $\underline{\text { den } \& \text { Search Type }=\text { Begins } \& \text { SearchPR }=01 \& A 1=\text { All }}$ \&Custom $=\&$ TABID $=1$

Szathmary, E. J. E., Ritenbaugh, C., \& Goodby, C.S. M. (1987). Dietary change and plasma glucose levels in an Amerindian population undergoing cultural transition. Social Science and Medicine, 24(10), 791-804. http://dx.doi.org/10.1016/02779536(87)90181-X

Thompson, S. (2005). Sustainability and vulnerability: Aboriginal Arctic food security in a toxic world. In F. Berkes, R. Huebert, H. Fast, M. Manseau, \& A. Diduck (Eds.), Breaking ice: Renewable resource and ocean management in the Canadian North (pp. 47-69). Calgary, Alberta: University of Calgary Press.

Thompson, S., Gulrukh, A., Ballard, M., Beardy, B., Islam, D., Lozeznik, V., \& Wong, K. (2011). Is community economic development putting healthy food on the table? Food sovereignty in northern Manitoba's Aboriginal communities. Journal of Aboriginal Economic Development, 7(2), 14-39. http://www.edo.ca/edo-tools/jaed 
Thompson, S., Gulrukh, A., \& Murthy, A. (2011). Back to traditional Aboriginal food. Alternatives Journal, 37(2), 13. http://www.alternativesjournal.ca/

Thompson, S., Lozeznik, V., \& Klatt, R. (Eds.). (2011). Harvesting hope in northern Manitoba communities [Video]. Retrieved from http://home.cc.umanitoba. ca/ thompso4/harvestinghope_doc.html

Thompson S., Kamal, A. G., Alam, M. A., \& Wiebe, J. (2012). Community development to feed the family in northern Manitoba communities: Evaluating food activities based on their food sovereignty, food security, and sustainable livelihood outcomes. Canadian Journal of Nonprofit and Social Economy Research, 3(2), 43-66. http://anserj.ca/index.php/cjnser

Thouez, J. P., Rannou, A., \& Foggin, P. (1989). The other face of development: Native population, health status and indicators of malnutrition - The case of the Cree and Inuit of northern Quebec.
Social Science and Medicine, 29(8), 965-974. http://dx.doi.org/10.1016/0277-9536(89)90052-X Wanyama, F.O., Develtere, P., \& Pollet, I. (2009). Reinventing the wheel? African cooperatives in a liberalized economic environment. Annals of Public and Cooperative Economics, 80(3), 361-392. http://dx.doi.org/10.1111/j.1467$\underline{8292.2009 .00390 . x}$

Willows, N. D., Hanley, A. J. G., \& Delormier, T. (2012). A socioecological framework to understand weight-related issues in Aboriginal children in Canada. Applied Physiology, Nutrition, and Metabolism, 37(1), 1-13. http://dx.doi.org/10.1139/h11-128

Willows, N., Veugelers, P., Raine, K., \& Kuhle, S. (2011) Associations between household food insecurity and health outcomes in the Aboriginal population (excluding reserves). Health Reports, 22(2), 15-20. http://www.statcan.gc.ca/pub/82-003$\underline{\mathrm{x} / 2011002 / \text { article/11435-eng.htm }}$ 